\title{
Evolving Dimensions of Judiciary in India
}

\author{
Meera Mathew*
}

\section{Abstract}

Law, being a mode of social engineering, cannot be viewed in isolation. The vitality of law as a living organism is primarily dependent on the judge's ability to interpret the same. From its nascent stage, the apex court in India has struggled with the issue of striking an equilibrium between economic and social reform programmes on the one hand and establishing the credibility of India by fostering respect for rule of law, on the other. This article deals with the changing dimensions of the Indian judiciary in playing a fundamental role in shaping the constitutional jurisprudence. The researcher seeks to examine the varying trends of the Supreme Court of India from the 1950's to 1970's, the 1980's in the light of the introduction of Public Interest Litigation, the post 1990 's with the approach to liberalization and finally, the time period from 2000, wherein the judiciary has taken up an activist role. Further, the judicial reforms initiated to enhance administration, including the introduction of the National Legal Services Authority (NALSA) under the Legal Services Authorities Act, 1987, the constitution of Lok Adalats to amicably settle and compromise the disputes pending in the courts, the providing of free and competent legal aid to the poor and weaker sections of the society in consonance with Article 39A of the Constitution, the establishment of specialized tribunals, both administrative and internal (for instance Administrative Tribunals and the Armed Forces Tribunal) as well as tribunals dealing with the disputes arising out of or associated with economic activities such as Competition Appellate Tribunal, Securities Appellate 
Tribunal etc. have been highlighted. However, the researcher urges that the need of the day is to strive towards better quality of government and enhanced administration and that the judiciary has an essential role to play in achieving that goal. In conclusion, it is stated that unless people's mental barriers towards reforms are broken, attempts of external remedies are bound to fail.

Keywords: Access to Justice, Judicial Activism, Judicial Review, Liberalization Public Interest Litigation.

\section{Introduction}

Law, being a mode of social engineering, cannot be analysed in isolation. ${ }^{1}$ The vitality of law as a living organism is primarily dependent on the judge's ability to pour life into it when the circumstances so demand by making new inroads into the law. Undoubtedly, no other Constitution can be found envisaging such a detailed cluster of provisions regarding a country's highest judicial organ, as the Indian Constitution. ${ }^{2}$ The Supreme Court of India is one of the most potent judicial organs in the world today, and it plays a fundamental role in determining constitutional jurisprudence in India. ${ }^{3}$

The Constitution of India was adopted with the dream of establishing a 'sovereign, socialist, secular, democratic republic' country. ${ }^{4}$ Among other goals, the Constitution aims to secure to all

* Research Associate, Indian Law Institute, New Delhi; meerathanks@gmail.com.

${ }^{1}$ Lee W. Potts, Law as a Tool of Social Engineering: The Case of the Republic of South Africa, 5 BOSTON INTL. \& COMP. LAW REV. 121 (1982).

2 K. G. Balakrishnan, Judicial Activism and the Enforcement of SocioEconomic Rights - The Indian Experience, Address Delivered at Dr. B.R. Ambedkar Memorial Lecture, (Jun. 13, 2009), http://www.supremecourtofindia.nic.in/speeches/speeches_2009/br_a mbedkar_lecture_-_london_june_2009.pdf.

${ }^{3}$ Id.

4 (Although the terms 'socialist' and 'secular" were inserted by the 42nd amendment in 1976, there are no doubts that the Constitution was both 
its citizens, justice (social, economic and political), liberty (of thought, expression, belief, faith and worship) and equality (of status and of opportunity). ${ }^{5}$ These aims were not merely inspirational, rather the founding fathers hoped to achieve a social revolution by means of the Constitution. ${ }^{6}$

In the early phases of post-independence, the Supreme Court grappled with the problem of striking an equilibrium between programmes of economic and social reform (for example, the land reform and land redistribution policy during the late 1950's and 1960 's) on one hand and instituting the credibility of the Indian State in terms of strengthening the rule of law and respecting the rights vested under the laws that preceded independence, and the very Constitution itself, on the other. ${ }^{7}$

However, the gradual movement towards judicial activism can be discerned from the 1970 's. ${ }^{8}$ In the numerous constitutional

socialist and secular from the very beginning). See, THE CONSTITUTION OF INDIA, Preamble.

${ }^{5} \mathrm{Id}$.

${ }^{6}$ (The social revolution meant, 'to get (India) out of the medievalism based on birth, religion, custom, and community and reconstruct her social structure on modern foundations of law, individual merit and social education'). See, GRANVILlE AUSTIN, THE INDIAN CONSTITUTION: CORNERSTONE OF A NATION 27 (Oxford: Clarendon Press, UK, 1966).

7 See, Shankari Prasad Singh Deo v. Union of India, A.I.R. 1951 S.C. 458 (upholding the validity of the first amendment to the Constitution that shielded land acquisition laws from legal challenge under Part III of the Constitution.) However, in later judgments starting with State of West Bengal v. Bella Banerjee, A.I.R. 1954 S.C. 170, the Court ruled that the meaning of 'compensation' in Art. 31(2) meant just equivalent for the property acquired, making meaningful land reform impossible. This in turn led to Parliament's adoption of the undesirable practice of shielding laws from constitutional challenge by placing them in the Ninth Schedule added to the Constitution by Parliament through the Constitutional (1st Amendment) Act, 1951.

8 Pritam Kumar Ghosh, Judicial Activism and Public Interest Litigation in India, 1 GJLS 77 (2013). 
decisions delivered by the Supreme Court, one of the most important among them being the Kesavananda Bharathi Case, ${ }^{9}$ the Court legitimated its interpretative method on the extent of parliament's amending power under Article 368 of the Indian constitution, by referring to the interests of the people of India. ${ }^{10}$

Expansion of judicial authority was witnessed in the post emergency phase, which saw the growth of the phenomenon of Public Interest Litigation (PIL), wherein the court reinterpreted the provisions of the fundamental rights liberally, in order to maximize the rights of the people, especially those of the disadvantaged sections of the society. The access to courts was facilitated by relaxing the technical rules of locus standi, along with other procedural and institutional innovations. ${ }^{11}$ The Court has been vigilant and pro-active in a plethora of cases, thereby adequately ensuring dynamism and vibrancy in the Indian Constitution. ${ }^{12}$

\section{Judicial Review and Public Interest Litigation}

The post-independence era saw the insertion of unequivocal provisions for judicial review, which was instrumental in giving effect to the rights guaranteed by the Constitution. The evolution of the scope of judicial review before the Indian courts could be seem in three dimensions - first, to ensure fairness in administrative action; second, to protect the constitutionally guaranteed fundamental rights of citizens; and third, to rule on questions of legislative competence between the centre and the states. ${ }^{13}$

${ }^{9}$ Kesavananda Bharati v. State of Kerala, 1973 (4) S.C.C. 225.

10 Arvind P. Datar, The Case That Saved Indian Democracy, The Hindu, (Apr. 24, 2013), http://www.thehindu.com/opinion/op-ed/the-case-thatsaved-indian-democracy/article4647800.ece.

11 SARBANi SEN, PUblic INTEREST LitigAtion IN INDIA: IMPLiCATIONS FOR LAW AND DEVELOPMENT, 8 (Mahanirban Calcutta Research Group, 2002).

12 Anirudh Krishnan, Where Should the Judiciary Draw the Line? The Hindu, (Apr. 26, 2014), http://www.thehindu.com/opinion/op-ed/whereshould-the-judiciary-draw-the-line/article5948452.ece.

13 Sanjay Satyanarayan Bang, Judicial Review of Legislative Action: A Tool to Balance the Supremacy of the Constitution, Address Before the XIV Annual 
One of the leading changes that transformed the judicial system and ushered a new era of judicial activism came in the form of the dilution of the requirement of 'locus standi' for the initiation of judicial proceedings. Since the intent was to ensure redressal to those who were too poor to move the court or were unaware of their legal rights and entitlements, the Court allowed actions to be brought on their behalf by social activists and lawyers alike. ${ }^{14}$ The Supreme Court of India pioneered the PIL movement, thereby throwing open the portals of courts to the common man. ${ }^{15}$

Till 1960s and 70s, the concept of litigation in India was in its nascent stage and was viewed in terms of a private pursuit for the vindication of private vested interests. Litigation consisted chiefly of actions initiated and pursued by specific individuals, addressing their own grievances.16 Thus, the initiation and continuance of litigation was seen as the prerogative of the injured person or the aggrieved party. It is the interventions of the Court that played a pivotal role in advancing the protection of civil liberties, the rights of workers, gender justice, accountability of public institutions, environmental conservation and the guarantee of socio-economic entitlements such as housing, health and education among others. This has not only strengthened the position of the judiciary vis-à-vis the other wings of government, but has also raised its prestige among the general populace. ${ }^{17}$

International Seminar on "Economics, Politics, and Civil Society" (Jan. 2, 2013).

14 K.G. Balakrishnan, Judicial Activism under the Indian Constitution, Address Delivered at Trinity College, Dublin (Oct. 14, 2009).

${ }_{15}$ P.N. Bhagwati \& C.J. Dias, The Judiciary in India: A Hunger and Thirst for Justice, 5 NUJS L. REV. 171 (2012).

16 Jamie Cassels, Judicial Activism and Public Interest Litigation in India: Attempting the Impossible?, 37 AM. J. COMP. L. 495 (1989).

17 Romi Jain, The Indian Supreme Court as Environmental Activist, THE DiPLOMAT, (Jan. 24, 2014), http://thediplomat.com/2014/01/the-indiansupreme-court-as-environmental-activist/. 
The unique model of public interest litigation that has evolved in India, not only addresses issues like consumer protection, gender justice, prevention of environmental pollution and ecological destruction, but is also directed towards finding social and political space for the disadvantaged and other vulnerable groups in the society. Justice Krishna Iyer in the Fertilizer Corporation Kamgar Union $\mathrm{Case}^{18}$ enumerated certain reasons for the liberalization of the rule of locus standi, namely that the exercise of state power to eradicate corruption may result in unrelated interference with individuals' rights and social justice which warrants liberal judicial review of administrative action and that the restrictive rules of standing are antithesis to a healthy system of administrative action and activism is essential for participative public justice.

Public Interest Litigation has therefore greatly widened the scope of access to justice as any public minded citizen is now given the opportunity to move the court in the interest of the general public. The Courts have given decisions in cases pertaining to different kinds of entitlements and protections, such as the availability of food, access to clean air, safe working conditions, political representation, affirmative action, anti-discrimination measures and the regulation of prison conditions among others. ${ }^{19}$

As a result, any citizen of India or any consumer group or social action group is now at liberty to approach the apex court to seek legal remedies in cases where their interests are at stake. Further, public interest cases may be filed without spending much on the heavy court fees that is required in cases of private civil litigation.

18 Fertilizer Corporation Kamgar Union v. Union of India and Ors., (1981) 1 S.C.C. 568.

19 People's Union for Democratic Rights v. Union of India, Bandhua Mukti Morcha v. Union of India, Shriram Food and Fertilizer case, Bhim Singh v. State of Jammu and Kashmir, (1985) 4 S.C.C. 677; See also Nilabati Behera v. State of Orissa, (1993) 2 S.C.C. 746; D.K. Basu v. Union of India, (1997) 1 S.C.C. 416. 


\section{Legal Responses to Liberalisation}

India, in the 1990 's, was a spectator to the significant shift towards a liberal political economy and to the development of legal education and legal service. Development occurred in a host of arenas, including corporate and commercial disputes, contractual disputes, intellectual property rights, especially trade mark infringement, patent infringement, copyright infringement, design infringement etc. ${ }^{20}$ Other ancillary areas that witnessed an increase in litigation were the fields of real estate law, construction law, maritime and admiralty law, sales and marketing, labour and employment law, pollution and environmental law, insurance law etc. This shows that the relationship between law and politics and law and economy, are mutually reinforcing. ${ }^{21}$

The reformation of legal institutions, including economic liberalization and reforms in democracy, correspond to the reforms in law and developmental activities. A progressive economy demands a predictable and transparent set of legal rules and an environment to ensure that business activities flourish.22 Subsequent to the shift in the economic policy towards liberalization, privatization and globalization, the law making process in developing countries like India started focusing primarily on market-oriented economic policies. The degree of judicial independence is correlated with that of economic growth. ${ }^{23}$ As shown by various studies, better performing courts lead to more

20 N.R. Madhava Menon, Law and Justice: A Look at the Role and Performance of Indian Judiciary, Address delivered at Berkeley Seminar Series on Law and Democracy (Sep. 2008) http:/ /indiandemocracy08.berkeley.edu/docs/Menon-LawANDJusticeALook\%20.pdf.

${ }^{21} I d$.

22 InTERnATIONAL LABOUR CONFERENCE, I.L.O., REPORT VI: THE PROMOTION OF SUSTAINABLE ENTERPRISES, (96th Sess. 2007).

23 Lars Feld \& Stefan Voigt, Economic Growth and Judicial Independence: Cross-Country Evidence Using a New Set of Indicators, 19(3) EUR. J. POL. ECON. 497 (2003). 
developed credit markets. A stronger judiciary is associated with more rapid growth of small as well as large firms in the economy. ${ }^{24}$

Business in India is booming and is expected to grow at a faster pace in the future as well. Over the last one and a half decades, business in India has grown exponentially and consequent to the unprecedented growth in business, the number of disputes has also increased. Majority of business communities have their own traditional methods of dispute resolution that have no direct connection with the formal legal system. ${ }^{25}$ For instance, jewellers, commodity traders, farmers, artisans, craftsmen, moneylenders etc. have well established methods of resolution of disputes, mostly through negotiation or mediation by a well known and reputed third party. However, in businesses involving higher stakes, numerous issues can crop up. The only recourse available in such cases is the regular court system.

\section{Changing Approach of the Judiciary}

The seeds of the concept of Public Interest Litigation in India were initially sown by Krishna Iyer J. in 1976, in Mumbai Kamgar Sabha v. Abdul Bhai. ${ }^{26}$ Akhil Bharatiya Shoshit Karmachari Sangh (Railway) v. Union of India, ${ }^{27}$ saw an unregistered association of workers being permitted to institute a writ petition under Article 32 of the Constitution for the redressal of their common grievances. Later, the idea of PIL flourished in S.P. Gupta and Ors. v. Union of India. ${ }^{28}$

Judicial Activism in India can be examined with reference to the review power of the Supreme Court under Article 32 of the Constitution, particularly in areas pertaining to public interest litigation. Through judicial activism, Supreme Court has played a pioneering role in the formulation of several principles like the

24 Id.

${ }^{25} I d$.

${ }^{26}$ Mumbai Kamgar Sabha, A.I.R. 1976 S.C. 1455.

27 Akhil Bharatiya Shoshit Karmachari Sangh (Railway), A.I.R. 1981 S.C. 298.

28 S.P. Gupta, A.I.R. 1982 S.C. 149. 
Principle of Absolute Liability in Oleum Gas Leak Case,29 Public Trust Doctrine in Kamalnath Case ${ }^{30}$ etc. Furthermore, a host of guidelines were also issued by the Court in diverse cases of PIL like the Ratlam Municipality Case ${ }^{31,}$ Taj Trapezium Case32, Ganga Pollution Case $^{33}$ etc.

In Rural Litigation and Entitlement Kendra v. State of U.P., ${ }^{34}$ the Supreme Court rejected the defence of res judicata, thereby refusing to withdraw the PIL and accordingly ordered compensation. In Sheela Barse I v. State of Maharashtra, ${ }^{35}$ the Supreme Court issued guidelines to curtail custodial violence. The meaning of right to life with human dignity available under Article 21 of the Constitution of India has been widened to the greatest possible extent.

Milestone cases like the Vishaka Case ${ }^{36}$ that set the procedural guidelines for protection of women in cases of sexual harassment at workplace, the Vineet Narain Case 37 that provided guidelines for checking delay in prosecution by the CBI, Ram Jethmalani v. Union of India wherein the Supreme Court formed the Special Investigation Team on black money, ${ }^{38}$ the order pertaining to the SEBI-Sahara Case, ${ }^{39}$ the Vodafone Tax Case ${ }^{40}$ etc. The following two

${ }^{29}$ M.C. Mehta v Union of India, A.I.R. 1987 S.C. 965.

${ }^{30}$ M.C. Mehta v Kamal Nath (1998) 1 S.C.C. 388.

${ }^{31}$ Municipal Council, Ratlam v. Vardhichand and Ors,1980 A.I.R. 1622, 1981 S.C.R. (1) 97.

32 M.C. Mehta v Union of India,1988 A.I.R. 1115, 1988 S.C.R. (2) 530.

${ }^{33} \mathrm{Id}$.

${ }^{34}$ Rural Litigation and Entitlement Kendra, 1989 A.I.R. 5941989 S.C.C. Supl. (1) 537 JT 1988 (4) 7101988 S.C.A.L.E. (2) 1574.

35 Sheela Barse, A.I.R. 1983 S.C. 378.

${ }^{36}$ Vishaka and Ors. v. State of Rajasthan, (1997) 6 S.C.C. 241.

37 Vineet Narain and Ors v. Union of India \& Anr., 1996 S.C.C. (2) 199.

${ }^{38}$ Ram Jethmalani, (2011) 8 S.C.C. 1.

${ }^{39}$ Sahara India Real Estate Corporation Limited v. Securities and Exchange Board of India, (2012) 10 S.C.C. 
decades also saw the Supreme Court exercise its powers with complete confidence in its independence, for instance, when the Court scrutinized the $2 \mathrm{G}$ spectrum scam. ${ }^{41}$ Moreover, in exercise of the powers conferred under Article 143(1) of the Constitution of India, the President of India can consult the Supreme Court for its advisory opinion and the judiciary can put across their opinion on matters of public importance.

In addition to this, scores of other decisions have been rendered by the Court regulating the mining mafia, ${ }^{42}$ bringing an end to manual scavenging, ${ }^{43}$ developing principles for distribution of state largesse, ${ }^{44}$ scathing denunciation of police atrocities, ${ }^{45}$ reading benevolent drug pricing into the patents regime ${ }^{46}$ and playing a pro-active role in the matters involving environment ${ }^{47}$ which have been welcomed by the society at large.

603.

40 Vodafone International Holdings B.V. v. Union of India and Anr., (2012) 6 S.C.C. 613.

41 Subramanian Swamy v. A. Raja (2012) 9 S.C.C. 257.

42 Samaj Parivartana Samudaya Ors. v. State of Karnataka and Ors., (2012) 7 S.C.C. 407.

${ }^{43}$ Union of India v. A.R. Narayanan, S.L.P. (Civil) No. 23086/2011.

${ }^{44}$ Akhil Bhartiya Upbhokta Congress v. State of M.P. (2011) 5 S.C.C. 29.

45 Prithipal Singh v. State of Punjab, (2012) 1 S.C.C. 10.

46 Novartis A.G. v. Union of India and Ors., (2013) 6 S.C.C. 1.

47 M.C. Mehta v. Union of India (1986) 2 S.C.C. 176; See also Indian Council for Enviro-Legal Action v.Union of India (1996) 3 S.C.C. 212; Vellore Citizens' Welfare Forum v. Union of India (1996) 5 S.C.C. 647; M.C. Mehta v. Kamal Nath, (1997) 1 S.C.C 388; S. Jagannath v. Union of India, (1997) 2 S.C.C. 87; M.C. Mehta (Taj Trapezium Matter) v. Union of India, (1997) 2 S.C.C. 353; M.C. Mehta (Calcutta Tanneries' Matter) v. Union of India, (1997) 2 S.C.C. 411; M.C. Mehta (Badkhal and Surajkund Lakes Matter) v. Union of India (1997) 3 S.C.C. 715; Bittu Sehgal v. Union of India, (2001) 9 S.C.C. 181 and M.C. Mehta v. Union of India, (2002) 4 S.C.C. 356. 
The judiciary also ensures fair working of political parties through various electoral reforms. Recently, the Supreme Court came out with the judgment in Lily Thomas v. Union of India ${ }^{8}$ by holding the view that 'if a sitting member of Parliament or state legislature is convicted and sentenced to not less than 2 years of imprisonment, he will get immediately disqualified from being member of the house.' This judgment will go a long way in cleaning our political system. In another recent case, the Supreme Court held that a voter could exercise the option of negative voting and reject all candidates as unworthy of being elected by pressing the None of the Above (NOTA) option in the electronic voting machine (EVM) ${ }^{49}$ The Court directed the Election Commission to provide the NOTA button in the EVM. The plethora of instances highlighted bears testimony to the ever evolving and changing dimensions of the judiciary in the country.

\section{Initiatives by the Judiciary to Promote Access to Justice}

The Indian judiciary has sustained tremendous changes over the years and is still in the process of development in order to effectively administer justice in consonance with the government's general policy.50 In addition to the setting up of courts and the enactment of legislation, electronic services have facilitated litigation process in the courts in an unprecedented manner resulting in faster dispensation of justice and case resolution, despite the heavy workload. 51

Amongst the most remarkable developments witnessed by the judiciary over the past few years is the diversity in cases adjudicated. Specialized courts and special committees have been

48 Lily Thomas, (2013) 7 S.C.C. 653.

49 People's Union for Civil Liberties and Anr. v. Union of India, 2013 (12) S.C.A.L.E. 165 .

50 Y.K. Sabharwal, Role of Judiciary in Good Governance, Address Delivered at Barrister B. M. Patnaik Memorial Lecture (Nov. 19, 2006).

51 Kishor Talukdar, eCourts - The Renaissance in Indian Judiciary, http://kamrupjudiciary.gov.in/e- journal.htm (last visited on Mar. 22, 2015). 
instituted to handle cases with distinctive features. There has also been an increasing interest in regulating the legal profession, in what seems to be a serious move towards advancing the profession, taking into account the importance of this vital sector and its influential role in the judicial system.

The major initiatives that have been witnessed are categorized as below:

\section{i. The Constitution of National Legal Services Authority (NALSA)}

NALSA has been constituted under the Legal Services Authorities Act, 1987 to monitor and evaluate implementation of legal services under the Act. The NALSA issues guidelines for the State Legal Services Authorities to implement the Legal Aid programmes and schemes throughout the country. The State Legal Services Authorities, District Legal Services Authorities, Taluka Legal Services Committees etc. are primarily required to discharge the following two main functions:- i) To provide free legal services to eligible persons and ii) To organize Lok Adalats for amicable settlement of disputes. ${ }^{52}$

\section{ii. The Constitution of Lok Adalats}

Lok Adalat, which has been given statutory status under the Legal Services Authorities Act, 1987 is a forum where disputes pending in the courts or are at pre-litigation stage are settled/compromised amicably. An award made by a Lok Adalat is deemed to be a decree of a civil court and is final and binding on all parties and no appeal can lie against the same. There have been consistent steps to render legal aid to the needy and the poor by way of holding Lok Adalats. Up to December 31, 2007, more

52 National Legal Services Authority India, http:/ / nalsa.gov.in/schemes.html (last visited on Mar. 22, 2015). 
than 6,98,000 Lok Adalats have been held in the different parts of the country wherein 1,86,00,000 cases were settled. Considering the figures with respect to Motor Vehicles Accident Claims, about 14.25 lakh cases have been resolved in total. These numbers bear testimony to a positive and successful development in the judicial field. ${ }^{53}$

\section{iii. Legal Aid}

Article 39A of the Constitution of India provides for free legal aid to the poor and weaker sections of the society and ensures justice for all. Article 14 and 22(1) of the constitution also make it obligatory for the State to ensure equality before law and provide a legal system that promotes justice based on equal opportunity to all. In 1987, the Legal Services Authorities Act was enacted by the Parliament, which came into force on 9th November, 1995 with the objective of establishing a nationwide uniform network for providing free and competent legal services to the weaker sections of the society on the basis of equal opportunity. ${ }^{54}$

\section{iv Specialized Tribunals}

Another instrumental initiative is the establishment of specialized tribunals. Specialized tribunals can be understood at two levels. Primary ones are the administrative and internal tribunals like the Administrative Tribunals ${ }^{55}$ and the Armed Forces

53 J.S. Bisht, Lok Adalat: A Mechanism of Alternate Dispute Resolution, 31 IBR 179 (2004).

54 G. Mallikarjun, Legal Aid in India and the Judicial Contribution, Universities, Intellectual Property Rights and Spinoffs: A Critical Evaluation 235 (2013), available at http:/ / www.commonlii.org/in/journals/NALSARLawRw/2013/13.pdf

55 Note: Administrative Tribunals Act, 1985 owes its origin to Article 323-A of the Constitution. 
Tribunal. 56 In addition to them and keeping in tune with the growing economic opportunities and the need to deal with the disputes efficiently, secondary tribunals like the Customs and Service Tax Appellate Tribunal, the Competition Appellate Tribunal, the Intellectual Property Appellate Board and the Copyright Board were constituted. Likewise, Securities Appellate Tribunal (SAT) was also constituted as a strong step towards ensuring a strong judicial system through the Securities and Exchange Board of India (SEBI).

\section{v. Alternative Dispute Resolution (ADR)}

In order to reduce the backlog of cases, there were efforts to resolve disputes by resorting to the method of Alternative Dispute Resolution (ADR), before they enter the portals of the court system. The Code of Civil Procedure, 1908 envisages the use of ADR under section 89 (inserted in 1999 and made applicable with effect from 2002) as a mandatory provision for the court to refer the dispute after the issues are framed for settlement outside the court. Likewise, Sections 265-A to 265-L of the Code of Criminal Procedure, 1973 were inserted in 2006 to deal with 'plea bargaining' that refers to pre-trial negotiations between the defendant, usually conducted between the counsel and the prosecution, during which the defendant agrees to plead guilty in exchange for certain concessions by the prosecutor. Thus, multiple tools have been made available for alternative dispute redressal including Arbitration, Mediation and Conciliation. ${ }^{57}$

56 Note: The Armed Forces Tribunal Act 2007, was passed by the Parliament and led to the formation of AFT with the power provided for the adjudication or trial of disputes and complaints with respect to commission, appointments, enrolments and conditions of service in respect of persons subject to the Army Act, 1950, The Navy Act, 1957 and the Air Force Act, 1950.

57 K. Ramakrishnan, Scope of Alternate Dispute Resolution in India, 1 JV (2005). 


\section{vi. The Right to Information Act}

The Right to Information Act, 2005 that empowers the people with the right to know has been efficiently implemented. Information Officers and Appellate Officers have been appointed under the Act to bring in transparency in the government process.

\section{vii The National Judicial Academy}

The National Judicial Academy has been set up by the Government of India to provide in-service training to Judicial Officers. The Academy was registered on 17 August, 1993 under the Societies Registration Act, 1860 to provide training and continuing education to judicial officers of States and Union Territories as well as ministerial officers working in the Supreme Court of India and the High Courts. The objectives of the programmes of the Academy include judicial reforms and policy development as well as research support services for greater efficiency, fairness, access and productivity. It also includes improvements in court administration and management for a litigant friendly justice system.

\section{viii E-Courts Mission Mode Project}

As per this project, all the courts in the country including the taluk courts are required to get computerised. In 2008, all the district courts were initialised to be digitised under the project. In order to create training modules and devising sustainable training strategies for the judges, the ECommittee (supported by a core group of researchers and functional/ technical staff of around 50 persons), after due deliberation, availed the services of Department of Electronics and Accreditation of Computer Classes (DoEACC), an autonomous society created and working under the Ministry of Communication and Information Technology, Government of India. One of the references made to the E-Committee is to create support systems by framing policies and implementation plan in following areas: a) To create a cadre of trainers and trouble-shooters for each court complex; b) To suggest ways and means to 
ensure the smooth running of the computer systems, including therein the availability of power supply, peripherals, stationary etc.; and c) To suggest methods to make access to justice and availability of information more litigant friendly.

\section{Conclusion}

Indian judiciary has taken giant strides that have resulted in the release of the people and the country from the shackles of colonialism that had not only squeezed the wealth of India but also fettered our freedom. The spirit of India and the genius of her people were thought to have been released from the subjugation and exploitation and we had assumed control over our destiny. ${ }^{58}$ The promises and commitment that India made to her people 64 years ago remain to be fulfilled and there are urgent tasks to be completed. To identify the challenges of the next millennium, India will have to clear the huge backlog of unredeemed promises. Hence, the need for today is to drive towards better quality of governance and enhanced administration.

As legal and judicial reforms advance in many countries, it is clear that there is a parallel need for attention towards the poor and the access to justice. It is not enough to train judges, create new case management tools and pass new laws. Different legal aid models can be tested and evaluated simultaneously during this reform process. Unless our mental barriers towards reform are broken, all attempts for external remedies are bound to fail. We must remember what Gandhiji said: "If you want to change anything, you be the change." 59

58 Jyoti Basu, India and the Challenges of the Twenty First Century, Address Delivered at the 30th Jawaharlal Nehru Memorial Lecture (Nov. 13, 1998), jyotibasu.net/?q=node/18.

59 Law Commission of India, Reforms in the Judiciary - Some Suggestions, Report No. 230 (2009). 